\title{
CCB RETENTION AND PENETRATION IN EUCALYPTUS FENCE POSTS IN FUNCTION OF CONDITION OF PRESERVATIVE TREATMENT
}

\author{
Pedro Augusto Fonseca Lima ${ }^{1 *}$, Fernando Nunes Gouveia ${ }^{2}$, Edy Eime Pereira Baraúna ${ }^{3}$, Carlos Roberto Sette $\mathrm{Jr}^{1}$ \\ ${ }^{1}$ Universidade Federal de Goiás, Departamento de Engenharia Florestal, Goiânia, Goiás, Brasil - *pedrofons@ gmail.com e \\ crsettejr@hotmail.com \\ ${ }^{2}$ Serviço Florestal Brasileiro, Laboratório de Produtos Florestais, Brasília, Distrito Federal, Brasil - fernando.gouveia@florestal.gov.br \\ ${ }^{3}$ Universidade Federal de Minas Gerais, Departamento de Engenharia Florestal, Montes Claros, Minas Gerais, Brasil - \\ edybarauna@uol.com.br
}

Received for publication: 05/12/2018 - Accepted for publication: 01/05/2019

\begin{abstract}
Resumo
Retenção e penetração do CCB em mouões de Eucalipto em função da condição do tratamento preservativo. $\mathrm{O}$ objetivo deste trabalho foi avaliar a eficiência do tratamento preservativo industrial com Borato de Cobre Cromatado $(\mathrm{CCB})$ em diferentes concentrações e tempo de pressão na autoclave, através da retenção e penetração na madeira de Eucalyptus. Foram selecionadas nove árvores de Eucalyptus urophylla x Eucalyptus grandis (Urograndis) derrubadas, descascadas e cortados mourões com comprimento de 2,20 metros e diâmetros variando de 9,2 a $15,4 \mathrm{~cm}$. Os mourões de Urograndis foram submetidos à autoclave industrial (método Bethel), em nove condições, em função da concentração de CCB e do tempo de pressão: 1,5\%, 2,0\% e 2,5\% e 30, 60 e 90 minutos. Em seguida, foram obtidos os corpos de prova e realizados os ensaios de retenção e penetração. A aplicação da concentração de 1,5\% de CCB e de 30 minutos de pressão na autoclave proporcionaram penetração e retenção de acordo com os níveis exigidos para a aplicação da madeira como mourões em contato com o solo, sendo as condições indicadas para o tratamento da madeira do Urograndis com CCB.

Palavras-chave: Concentração, Tempo de pressão, Borato de Cobre Cromatado
\end{abstract}

\section{Abstract}

The objective of this work was to evaluate the efficiency of the industrial preservative treatment with Chromated Copper Borate (CCB) in different concentrations and pressure time in the autoclave through retention and penetration in Eucalyptus wood. Nine Eucalyptus urophylla $x$ Eucalyptus grandis (Urograndis) trees were felled, debarking and cut into fence posts with a length of 2.20 meters and diameters ranging from 9.2 to $15.4 \mathrm{~cm}$. The Urograndis fence posts were submitted to the industrial autoclave (Bethel method) in nine conditions, according to the CCB concentration and the pressure times: $1.5 \%, 2.0 \%$, and $2.5 \%$ and 30,60 and 90 minutes. The retention and penetration tests were performed. The application of $1.5 \%$ CCB concentration and 30 minutes of pressure in the autoclave provided penetration and retention according to the levels required for the application of the wood as fence posts in contact with the soil, and those are the conditions indicated for the treatment of Urograndis wood with CCB.

Keywords: Concentration, Pressure Time, Chromated Copper Borate.

\section{INTRODUCTION}

Wood is a material of organic origin, and depending on the environmental conditions to which it is submitted it might be deteriorated by biological degradation agents (bacteria, fungi, insects), as well as by chemical reactions (LOPES et al., 2017). When used in its solid form (e.g., fence posts), the wood in contact with the soil undergoes an interaction of moisture and aeration in such context, favoring the development of fungi (VIDAL et al., 2015; SILVEIRA et al., 2018). This fact is common in woods from species of low natural durability, as it is the case of Eucalyptus and its hybrids, mainly due to their anatomical, chemical and physical characteristics, directly affecting the wood quality.

Despite its low natural durability, Eucalyptus wood is the main source of raw material for the production of cellulose pulp, energy and solid products, as in the furniture industry and rural construction, such as fence posts (INDÚSTRIA BRASIELIRA DE ÁRVORES, 2018). For applications in their solid form, the treatment of Eucalyptus wood becomes a fundamental part, mainly in contact with soil or under conditions that favour the attack of xylophage agents, as it improves its resistance to deterioration.

The main wood preservative treatment methods in Brazil are those performed under pressure in an autoclave using full cell impregnation method (Bethel method). In general, industrial methods (with an autoclave and presence of pressure) are regarded as more environmentally safe and efficient compared to non-pressure methods because of the degree of control that industrial components provide during the wood treatment process

FLORESTA, Curitiba, PR, v. 50, n. 2, p. 1345 - 1352, abr/jun 2020.

Lima, P. A. F. et.al.

ISSN eletrônico 1982-4688

DOI: $10.5380 /$ rf.v50 i2. 63737 
(VIDAL et al., 2015). For example, studies that used industrial treatment under a cell-filled method (SALESCAMPOS et al., 2003; VALLE et al., 2013) under different conditions found satisfactory results for retention.

According to Instituto Brasileiro do Meio Ambiente e dos Recursos Naturais Renováveis (IBAMA) (2017), the main preservatives used in industrial processes in Brazil are Chromated Copper Arsenate (CCA), Chromated Copper Borate (CCB) and Creosote.

Although CCA is the most used preservative in Brazil (VIDAL et al., 2015), CCB is a viable option due to (i) lower boron toxicity in comparison with arsenic, being safer to use and potentially less damaging to the environment; (ii) availability in the market, (iii) greater flexibility in the treatment process and others (LEPAGE, 2010; SHANU et al., 2015; GALLIO et al., 2017).

After the application of the preservative solution, retention and penetration tests are adopted to verify the success of the treatment (VALLE et al., 2013, AMARAL et al., 2014; LOPES et al., 2017). The retention analysis is classified by categories of wood use expressed by ABNT NBR 9480 (ASSOCIAÇÃO BRASILEIRA DE NORMAS TÉCNICAS, 2009). According to this standard, minimum retention of the preservative solution for fence posts in direct contact with soil is $6.5 \mathrm{~kg}$ of active ingredient per $\mathrm{m}^{3}$ of wood. The penetration analysis can either be performed qualitatively (SALES-CAMPOS et al., 2003) by observing depth levels, or quantitatively (LOPES et al., 2017), being considered satisfactory when reaching at least $1.0 \mathrm{~cm}$ of penetration.

When opting for the industrial treatment of wood, the analyzes of these parameters will assess the effectiveness of the treatment; for example, if the concentration of active ingredients of the preservative solution was sufficient, and if the pressure time adopted in the autoclave during the treatment allowed the penetration of the preservative solution (MORENO et al., 2008; SCHNEID et al., 2013). Papers which have evaluated these parameters in function of the pressure time in the autoclave and the concentration of the preservative solution have mostly been performed using CCA, with a scarcity of works which have evaluated the conditions adopting CCB. In addition, the time spent during the wood treatment process as well as the concentration of active ingredients in the preservative solution are essential components to improve the production chain, reducing time and product waste when determining the values for concentration and time that are sufficient to ensure retention and penetration of the preservative solution and the quality of the treated wood.

Thus, the results of this paper is important to establish a standard proposal regarding the concentration of $\mathrm{CCB}$ and the pressure time for Eucalyptus grandis x Eucalyptus urophylla (Urograndis) wood. The objective of this work was to evaluate the efficiency of the industrial preservative treatment with CCB in different concentrations and pressure time in the autoclave through retention and penetration in Urograndis wood.

\section{MATERIAL AND METHODS}

\section{Study site, sample collection and preservative treatment}

The evaluation of treated wood was carried out on Eucalyptus urophylla S.T. Blake x Eucalyptus grandis W. Mill ex Maiden (Urograndis) from a forest plantation at seven-year-old, located in the municipality of Nerópolis, Goiás, Brazil at $16^{\circ} 18^{\prime} 28.85^{\prime \prime} \mathrm{S}$ and $49^{\circ} 13^{\prime} 3.80^{\prime \prime} \mathrm{W}$, with $852 \mathrm{~m}$ of altitude. The climate is Aw according to the Köppen classification, with wet and rainy summers (October to April) and dry winters (May to September). The average annual precipitation is $1,432 \mathrm{~mm}$ and average temperature is $20.4{ }^{\circ} \mathrm{C}$ and $24.4{ }^{\circ} \mathrm{C}$ in the colder and warmer months, respectively.

Nine Urograndis trees were selected and then felled, debarked and cut into fence posts, with length of 2.20 meters and diameters ranging from 9.2 to $15.4 \mathrm{~cm}$ ( 36 fence posts in total).

The Urograndis fence posts were dried outdoors for 60 days until reaching $25 \%$ of humidity. The fence posts were submitted to the industrial preservative treatment with Chromated Copper Borate (CCB) in an autoclave, in a full-cell process (Bethell method), with a pressure of $12 \mathrm{kgf} \mathrm{cm}^{-2}$ at concentrations of $1.5 ; 2.0$ and $2.5 \%$ and pressure time of 30, 60 and $90 \mathrm{~min}$. For each condition (concentration x pressure time), 4 fence posts were used, totalling 36 treated fence posts.

The concentrations and pressure times used in this study were defined as being the parameters commonly used in the country's wood treatment plants (TORRES et al., 2011; LOPES et al., 2017). After the preservative treatment at the different concentrations and times, the fence posts were dried outdoors for 30 days for the preservative fixation.

\section{Samples preparation and determination of the retention and penetration}

The CBB penetration and retention assays in Urograndis fence posts were performed on freshly cut crosssections taken perpendicular to the growth rings (wooden discs). Four wooden discs were removed from each fence post, resulting in 144 discs (36 treated fence posts x 4 wooden discs per fence post $=144$ wooden discs). 
Then, two wooden discs per fence post was randomly selected for each analysis (retention and penetration) (Figure 1).

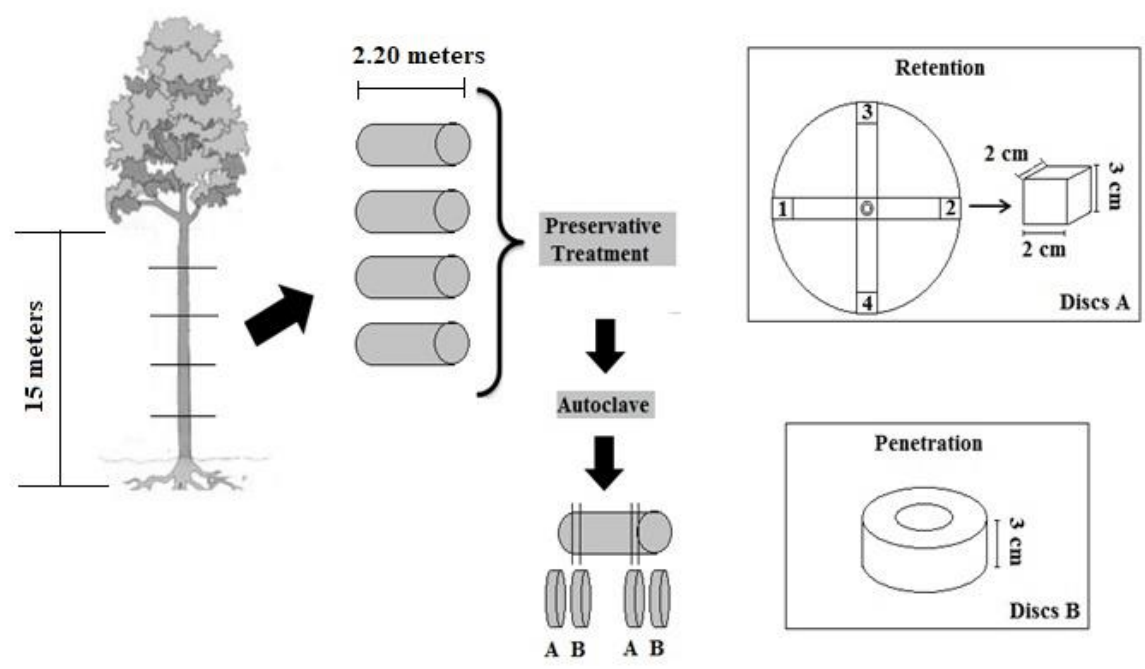

Figure 1. Scheme for obtaining samples to the retention and penetration analysis.

Figura 1. Esquema para obtenção de amostras para análise de retenção e penetração.

The evaluation of the retention and penetration of the CCB solution in the wood was carried out based on the methodology described by ABNT NBR 6232 (ASSOCIAÇÃO BRASILEIRA DE NORMAS TÉCNICAS, 2013). In order to determine the penetration of the preservative, the wooden discs were polished and pulverized with Chromoazulrol S, solution to determine the penetration of the copper on one side and solution of Polyvinyl alcohol and iodine for determination of boron penetration on the other side. Then, the qualitative penetration levels of the preservatives were classified in the treated wood pieces, according to the classification of Sales-Campos et al. (2003) (Figure 2), and quantitative penetration, as proposed by Lopes et al. (2017): for each disc, two perpendicular diameters were marked by the pith and the penetration of the product was measured using a pachymeter.

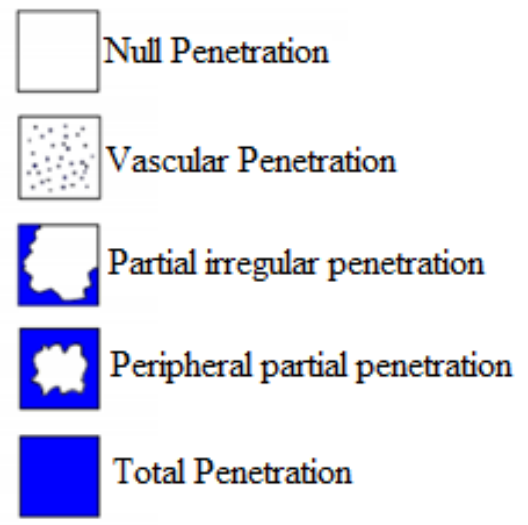

Figure 2. Criterion used to classify the penetration of the CCB in the wood (Source: SALES-CAMPOS et al., 2003).

Figura 2. Critério usado para classificação da penetração do CCB na madeira (Fonte: SALES-CAMPOS et al., 2003).

The steps for CCB retention analysis were:

(a) From each wooden disc, four samples were obtained from the treatable region (sapwood): $2.0 \times 2.0$ x $3.0 \mathrm{~cm}$ - width, thickness and height, respectively (Figure 1);

(b) The samples were crushed and submitted to milling process; 
(c) Obtaining the material in 60 mesh granulometry using an orbital shaker of intermittent sieves to allow digestion of the samples and determine the retention in the laboratory.

The determination of the amount of each elements (copper, chromium and boron) introduced by the treatment, per treated wood cubic unit (retention), was carried out in the Chemical Analysis Laboratory of the Aqualit Company, located in Goiânia, Goiás, Brazil. The technique of inductively coupled plasma optical emission spectrometry (ICP - OEC, PerkinElmer, Optima 7800 DV), equipped with a concentric nebulizer and cyclonic nebulization chamber, was used to quantify the elements copper, chromium and boron retained in the wood. This technique is one of the most used to verify metals retained in wood, as suggested by Vivian et al. (2012). The sample digestion was performed according to the methodology proposed by Paes et al. (2014). The obtained values were converted into retention units ( $\mathrm{kg}$ of active ingredient per $\mathrm{m}^{3}$ of treated wood).

The effect of conditions according to the CCB concentration and the pressure time were evaluated by analysis of variance (ANOVA). The experimental design was completely randomized, with nine treatments arranged in a $3 \times 3$ factorial scheme, with 3 concentrations $(1.5 ; 2.0$ and $2.5 \%)$ and three pressure times $(30,60$ and 90 min.). The means were compared by Tukey's test, at a level of 5\% of probability.

\section{RESULTS}

\section{CCB Retention}

The total retention of CCB for Urograndis wood submitted to autoclave preservative treatment as a function of pressure time was satisfactory for all conditions (time) employed, with significant differences (Table 1). Although the highest retention was observed in the condition that used the longest pressure time (60 and 90 minutes), the shortest time applied is sufficient according to ABNT NBR 9480 (ASSOCIAÇÃO BRASILEIRA DE NORMAS TÉCNICAS, 2009), which states the minimum retention should be $6.5 \mathrm{~kg}$ active ingredient per $\mathrm{m}^{3}$ to treated fence post in contact with soil. In addition, significant differences were also found for retention in 30 minutes in comparison with the others, when Chromium, Boron and Copper ingredients are evaluated separately, demonstrating increased retention of these elements proportional to the increase in autoclave pressure time.

Table 1. CCB retention as a function of time in the autoclave.

Tabela 1. Retenção de CCB em função do tempo na autoclave.

\begin{tabular}{|c|c|c|c|c|}
\hline $\begin{array}{c}\text { Condition } \\
\text { (time in minutes) }\end{array}$ & $\begin{array}{c}\text { Boron } \\
\left(\mathrm{kg} \mathrm{m}^{-3}\right)\end{array}$ & $\begin{array}{l}\text { Chrome } \\
\left(\mathrm{kg} \mathrm{m}^{-3}\right) \\
\end{array}$ & $\begin{array}{l}\text { Copper } \\
\left(\mathrm{kg} \mathrm{m}^{-3}\right) \\
\end{array}$ & $\begin{array}{c}\text { Total retention } \\
\left(\mathrm{kg} \mathrm{m}^{-3}\right)\end{array}$ \\
\hline 30 & $0.60 \mathrm{~b}(5.27)$ & $5.56 \mathrm{~b}(3.19)$ & $3.03 \mathrm{~b}(5.20)$ & $9.19 \mathrm{~b}(6.19)$ \\
\hline 60 & $0.66 \mathrm{ab}(4.26)$ & $6.00 \mathrm{a}(5.16)$ & $3.26 \mathrm{a}(3.16)$ & 9.93 a (5.16) \\
\hline 90 & $0.72 \mathrm{a}(3.26)$ & $6.44 \mathrm{a}(3.17)$ & $3.48 \mathrm{a}(4.17)$ & $10.65 \mathrm{a}(3.17)$ \\
\hline
\end{tabular}

Averages followed by the same letter do not differ statistically from one another $(\mathrm{p}>0.05)$. Coefficient of variation between parentheses.

For the total retention of the preservative product of the autoclaved wood at different concentrations of $\mathrm{CCB}$, it was observed that all conditions were able to demonstrate efficiency (Table 2). The lowest average found in the condition that used $1.5 \%$ of $\mathrm{CCB}$ presented total retention of $8.01 \mathrm{~kg} \mathrm{~m}^{-3}$, above that required for the commercialization of wood in the form of fence posts in contact with the soil. Both the total retention and the isolated retention of the components of the solution (Chrome, Boron and Copper) show proportional increase to the greater amount of concentration of CCB used in the treatment of wood.

Table 2. CCB retention as a function of the concentration of the solution in the treatment.

Tabela 2. Retenção de CCB em função da concentração da solução no tratamento.

\begin{tabular}{ccccc}
\hline $\begin{array}{c}\text { Condition } \\
(\text { concentration in \%) }\end{array}$ & $\begin{array}{c}\text { Boron } \\
\left(\mathrm{kg} \mathrm{m}^{-3}\right)\end{array}$ & $\begin{array}{c}\text { Chrome } \\
\left(\mathrm{kg} \mathrm{m}^{-3}\right)\end{array}$ & $\begin{array}{c}\text { Copper } \\
\left(\mathrm{kg} \mathrm{m}^{-3}\right)\end{array}$ & $\begin{array}{c}\text { Total retention } \\
\left(\mathrm{kg} \mathrm{m}^{-3}\right)\end{array}$ \\
\hline 1.5 & $0.54 \mathrm{~b}(4.26)$ & $4.84 \mathrm{c}(3.17)$ & $2.62 \mathrm{c}(5.17)$ & $8.01 \mathrm{c}(5.16)$ \\
2.0 & $0.61 \mathrm{~b}(3.27)$ & $5.91 \mathrm{~b}(2.11)$ & $3.27 \mathrm{~b}(5.13)$ & $9.8 \mathrm{~b}(4.12)$ \\
2.5 & $0.84 \mathrm{a}(2.15)$ & $7.25 \mathrm{a}(3.14)$ & $3.86 \mathrm{a}(4.14)$ & $11.96 \mathrm{a}(4.13)$ \\
\hline
\end{tabular}

Averages followed by the same letter do not differ statistically from one another $(\mathrm{p}>0.05)$. Coefficient of variation between parentheses. 


\section{CCB Penetration}

In the qualitative analysis of $\mathrm{CCB}$ penetration in the Urograndis fence posts, regularities were observed in the preservative distribution in all the applied conditions (Figure 3). Total penetration was indicated by a blue color (indicated in Figure 3 by the letter A), due copper penetration, from the peripheral part of the sapwood to the heartwood/sapwood transition band. It was also observed that the presence of wood defects such as drying cracks influenced the CCB penetration in the fence posts, and did not present a preservative solution in the extension of the crack section of the sapwood.

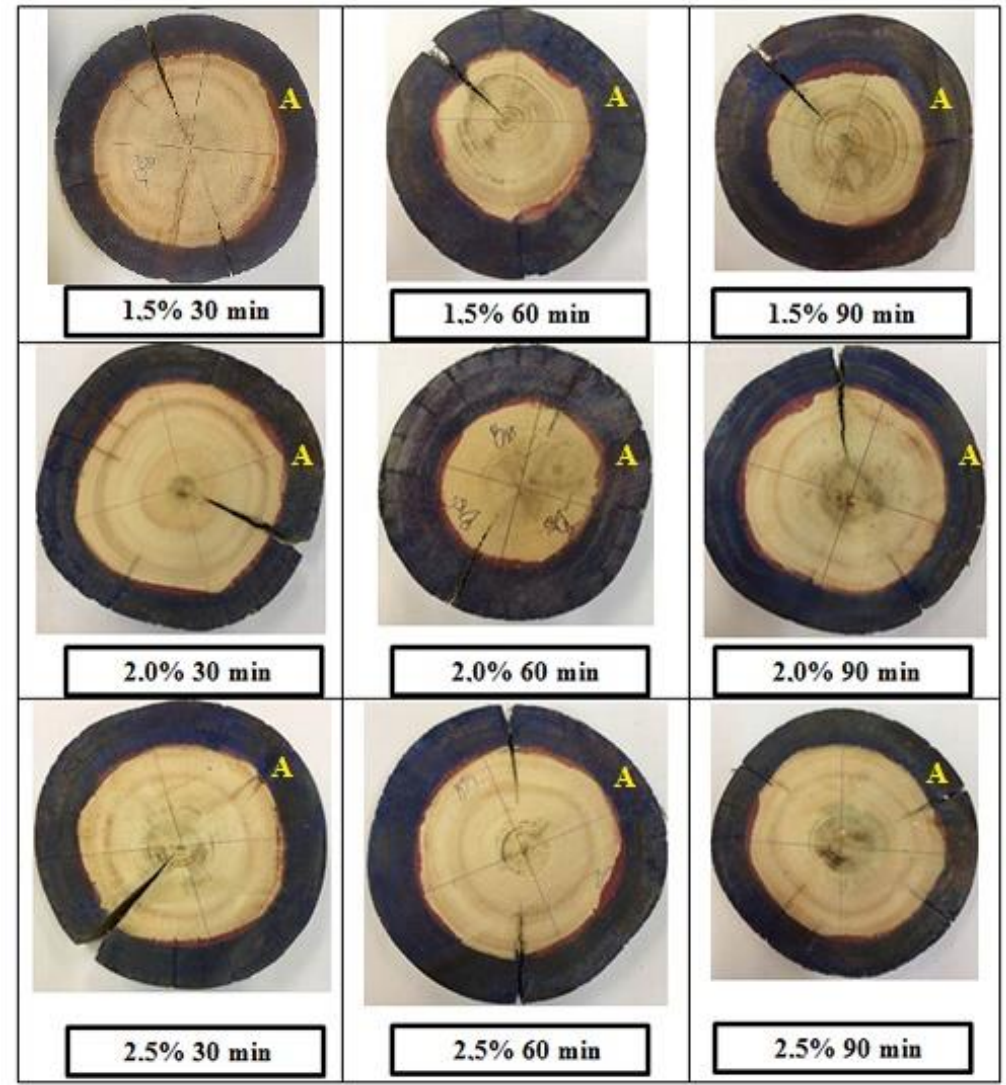

Figure 3. Qualitative penetration of CCB in different conditions. Letter A indicates copper penetration. Figura 3.Penetração qualitativa de CCB nas diferentes condições. Letra A indica a penetração do cobre.

For the quantitative analysis of CCB penetration in the treated wood as a function of autoclave pressure time and concentration of the preservative product, it was observed that all the applied conditions obtained satisfactory penetration depths (Table 3), without significant differences.

Table 3. Quantitative penetration of CCB as a function of time and concentration of the preservative solution. Tabela 3. Penetração quantitativa de CCB em função do tempo e da concentração da solução preservativa.

\begin{tabular}{ccc}
\hline Condition & Penetration $(\mathrm{mm})$ & Classification* \\
\hline $30 \mathrm{~min}$ & $20.55 \mathrm{a}(6.16)$ & Total Penetration \\
$60 \mathrm{~min}$ & $20.36 \mathrm{a}(5.15)$ & Total Penetration \\
$90 \mathrm{~min}$ & $20.50 \mathrm{a}(6.36)$ & Total Penetration \\
\hline $1.5 \%$ & $20.50 \mathrm{a}(6.56)$ & Total Penetration \\
$2.0 \%$ & $20.77 \mathrm{a}(6.06)$ & Total Penetration \\
$2.5 \%$ & $20.30 \mathrm{a}(6.26)$ & Total Penetration \\
\hline
\end{tabular}

Averages followed by the same letter do not differ statistically from one another ( $\mathrm{p}>0.05)$. Coefficient of variation between parentheses. * Source: Sales-Campos et al. (2003). 


\section{DISCUSSION}

\section{Retention}

The results of the analysis of total retention and each active ingredients (a.i.) of CCB showed that all the conditions used reached out the minimum necessary retention to protect the wood when in contact with the ground. The NBR 9480 (ABNT, 2009) states that, in order for the wood to be used in this condition (in contact with the soil), the minimum retention should be $6.5 \mathrm{~kg}$ a.i m$~^{-3}$. Therefore, the different conditions applied in the wood treatment ensure compliance of the standard for Urograndis wood against deteriorating organisms in contact with the soil. It is also noted that the application of the minimum conditions adopted in this work of $1.5 \%$ CCB concentration and pressure of 30 minutes in the autoclave are sufficient to reach the quality of the treated wood required for use in contact with the soil.

This result indicates an economic advantage in view of reducing costs associated with higher concentrations of preservatives and residence time in the autoclave. In other words, the use of preservative solutions with higher concentrations of active ingredients results in higher costs during the autoclave treatment, as well as the longer pressure in the autoclave reduces the efficiency in the treatment chain. In evaluating CCA retention in Eucalyptus saligna and Eucalyptus cloeziana wood autoclaved with $2.0 \%$ active ingredients, with a pressure of $12 \mathrm{kgf} \mathrm{cm}^{-2}$, at different pressure times (60, 90 and 120 minutes), Schneid et al. (2013) found satisfactory values for all analyzed conditions, with the time of $60 \mathrm{~min}$ being indicated as being more economically feasible. Their efficiency results match ours and it shows that CCB is as suitable as CCA concerning retention and penetration

The significant differences found for the means of total retention and each active ingredients of the solution (Chromium, Boron and Copper) for the different applied conditions show an enhance as a function of the increase in pressure time and the preservative concentration. However, it is worth mentioning that the lower pressure time used (30 minutes) and the lower CCB concentration (1.5\%) provided satisfactory retention with respect to the indication of NBR 9480 (ABNT, 2009). This situation indicates high efficiency of the industrial treatment, as well as determining the likely economic viability for the different applied treatments giving protection to the Urograndis wood.

In evaluating the CCA retention of five Eucalyptus species and the Urograndis hybrid, Lima et al. (2014) found satisfactory retentions (ranging from 7.8 to $9.2 \mathrm{~kg}$ a.i. $\mathrm{m}^{-3}$ ) for all masts treated in a cell-filled industrial treatment with a pressure of $12 \mathrm{kgf} \mathrm{cm}^{-2}$ maintained for 2 hours in the autoclave.

The level of preservative retention influences the effectiveness of the treatment as well as the durability of the treated wood (VIDAL et al., 2015). The factors that may affect product retention is the treatment method, wood age and concentration of the solution applied in the treatment (VIDAL et al., 2015). In this way, it can be affirmed that all the factors employed during the treatment of Urograndis wood at 7 years of age were positive, so that the retention of CCB in a full-cell industrial method demonstrated treatment efficiency.

\section{Penetration}

For the qualitative assessment of CCB penetration, an intense blue coloration found from the periphery of the sapwood to the transition between heartwood/sapwood showed total penetration for all applied conditions according to the classification of Sales-Campos et al. (2003), with regular distribution throughout the sapwood section. According to NBR 9480 (ABNT, 2009), it is expected to penetrate $100 \%$ of the sapwood when the wood is treated under industrial conditions with water soluble solutions, which was observed in the present work for the treatment using different $\mathrm{CCB}$ concentrations and pressure times in the autoclave. In evaluating the qualitative penetration of CCA with a concentration of $2.0 \%$ in Eucalyptus urophylla S.T. Blake in industrial treatment, Valle et al. (2013) found total penetration and regular distribution throughout the sapwood region.

For the quantitative penetration classification of the preservative product in the treated wood, Torres et al. (2011) and Lopes et al. (2017) stated that it is considered adequate when penetration reaches a depth equal to or greater than $10.00 \mathrm{~mm}$. All the conditions, both as a function of the CCB concentration and as a function of the pressure time in the autoclave, obtained penetration to a depth above that indicated in the literature, throughout the tractable region of the wood (sapwood). Lopes et al. (2017) affirmed that greater penetrations are found in woods of smaller diameters, as well as for bigger proportions of sapwood. This fact may explain the high penetration found in the present study.

Thus, considering qualitative and quantitative analyzes, it was possible to conclude that all the conditions applied during the treatment of Urograndis wood with CCB provided high quality during the wood preservation process. 


\section{CONCLUSION}

- Industrial preservative treatment with $\mathrm{CCB}$ demonstrated adequate retention and penetration for all applied conditions;

- The application of $1.5 \%$ CCB concentration and 30 minutes of pressure in the autoclave provided penetration and retention according to the levels required for the application of the wood as fence posts in contact with the soil, and these are the conditions indicated for the treatment of Urograndis wood with CCB.

\section{REFERENCES}

AMARAL, L. S.; SILVA, J. R. M.; HEIN, P. R. G.; TRUGILHO, P. F. Influência do diâmetro e umidade no tratamento preservativo de moirões de Eucalyptus. Revista Árvore, Viçosa, v. 38, n. 5, p. 919 - 925, 2014.

ASSOCIAÇÃO BRASILEIRA DE NORMAS TÉCNICAS - ABNT. NBR 6232: penetração e retenção de preservativos em madeira tratada sob pressão. Rio de Janeiro, 2013. 16 p.

ASSOCIAÇÃO BRASILEIRA DE NORMAS TÉCNICAS - ABNT. NBR 9480: peças roliças preservadas de eucalipto para construções rurais: requisitos. Rio de Janeiro, 2009. 12 p.

GALLIO, E.; GATTO, D. A.; LAZAROTTO, M.; BELTRAME, R. Eficiência de preservantes fungicidas em madeiras de duas espécies florestais submetidas à deterioração por fungo. Nativa, Sinop, v. 5, n. 6, p. 434 - 439, 2017.

INDÚSTRIA BRASILEIRA DE ÁRVORES - IBÁ. Relatório anual, ano base de 2017. Disponível em: <http://iba.org/images/shared/Biblioteca/IBA_RelatorioAnual2017.pdf> Acesso em 22/01/2018.

INSTITUTO BRASILEIRO DO MEIO AMBIENTE E DOS RECURSOS NATURAIS RENOVÁVEIS IBAMA. Qualidade ambiental: preservativos de madeira. Disponível em: <http://www.ibama.gov.br/phocadownload/qualidadeambiental/preservativos_de_madeira/2017registrados/tanalith-72-cca-c.pdf> Acesso em: 25/02/2017.

LEPAGE. E. S. Preservativo sustentável com longo histórico de eficiência. Revista Referência, Curitiba, s/v., s/n., p. 80-83, 2010.

LIMA, F. C. C.; SANTORI, M. S.; SEVERO, E. T. D.; COLANEGO, F. W. Tratamento de seis espécies de Eucalyptus spp., utilizando Arseniato de Cobre Cromatado (CCA-C) em método industrial com autoclave. Revista Científica Eletrônica de Engenharia Florestal, Garça, v. 23, n. 1, p. 71 - 90, 2014.

LOPES, D. J. V.; PAES, J. B.; JANKOWSKY, I. P.; SEGUNDINHO, P. G. A.; VIDAURRE, G. B. Influências do diâmetro e umidade da madeira na qualidade do tratamento preservativo. Floresta e Ambiente, Seropédica, v. 24, s/n., 10 p., 2017.

MORENO, G; PAN, E.; WOTTITIZ, A.; CARRANZA, M. E.; SEGIENOWICZ, R. Impregnación de la madera de orígenes de Pinus taeda implantados en la localidad de Famaillá, Provincia de Tucumán. Quebracho, Santiago del Estero, s/v., n. 15, p. 42-46, 2008.

PAES J.B.; LOPES, D.J.V.; GONÇALVES, F.G., BRITO, F.M.S., LOMBARDI, LR. Efeito da concentração na ascensão de soluções preservativas preparadas com CCB em moirões de Eucalyptus. Floresta e Ambiente, Seropédica, v. 21, n. 3, p 384-393. 2014.

SALES-CAMPOS, C.; VIANEZ, B. F.; MENDONÇA, M.S. Estudo da variabilidade da retenção do preservante CCA tipo A na madeira de BrosimumrubescensTaub. Moraceae - (Pau-rainha) uma espécie madeireira da região Amazônica. Revista Árvore, Viçosa, v. 27, n. 6, p. 845 - 853, 2003.

SCHNEID, E.; GATTO, D.A.; CADEMARTORI, P.H.G. Avaliação do tratamento sob pressão de postes de Eucalyptus saligna e Eucalyptus cloeziana com CCA-C. Scientia Forestalis, Piracicaba, v. 41, n. 100, p. 541547, 2013.

SILVEIRA, A.G.; BALDIN, T.; VIDRANO, B.R.A.; SANTINI, E.J.; TALGATTI, M.; TREVISAN, R. Quality of Hovenia dulcis Thunb. round fence posts submitted to preservative treatment. Floresta, Curitiba, v. 48, n. 1, p. 59-66, 2018. 
SHANU, S.A.; DAS, A.K.; RAHMAN1, M.M.; ASHADUZZAMAN, M. Effect of Chromate-Copper-Boron preservative treatment on physical and mechanical properties of Raj koroi (Albizia richardiana) wood. Bangladesh Journal os Scientific and Industrial Research, Dhaka, v. 50, n. 3, p. 189-192, 2015.

TORRES, P. M. A.; PAES, J. B.; LIRA, J. A. F. O.;NASCIMENTO, J. W. B. Tratamento preservativo da madeira juvenil de Eucalyptu scamaldulensis Dehnh. pelo método de substituição de seiva. Cerne, Lavras, v. 17, n. 2, p. $275-282,2011$.

VALLE, M. L. A.; SILVA, J. C.; LUCIA, R. M. D.; EVANGELISTA, W. V. Retenção e penetração de CCA em madeira de primeira e segunda rotação de Eucalyptusurophylla S.T. Blake. Ciência Florestal, Santa Maria, v. 23, n. 2, p. $481-490,2013$.

VIDAL, J. M.; EVANGELISTA, W. V.; SILVA, J. C.; JANKOWSKY, I. P. Preservação de madeiras no Brasil: histórico, cenário atual e tendências. Ciência Florestal, Santa Maria, v. 25, n. 1, p. 257 - 271, 2015.

VIVIAN, M. A.; SANTINI, E. J.; MODES, K. S.; MORAIS, W. W. C. Qualidade do tratamento preservativo em autoclave para a madeira de Eucalyptus grandis e Eucalyptus cloeziana. Scientia Florestalis, Piracicaba, v. 40, n. 96, p. $445-453,2012$. 